\begin{tabular}{|c|c|c|}
\hline UNNFS & $\begin{array}{l}\text { Jurnal Fisika } 10 \text { (2) (2020) 19-26 } \\
\text { Jurnal Fisika } \\
\text { https://journal.unnes.ac.id/nju/index.php/jf/index }\end{array}$ & Jurnal Fisika \\
\hline & & \\
\hline
\end{tabular}

\title{
Pengaruh Faktor Eksposi Digital Radiography (DR) terhadap Nilai Kontras pada Citra Phantom sebagai Organ Tiruan
}

\author{
Andhika Dwi Anggara ${ }^{1 凶}$ dan Nila Prasetya Aryani ${ }^{2}$ \\ ${ }^{1}$ Program Studi Pendidikan Kedokteran, Fakultas Kedokteran, Universitas Islam Sultan Agung, Indonesia \\ ${ }^{2}$ Jurusan Fisika, Fakultas Matematika dan Ilmu Pengetahuan Alam, Universitas Negeri Semarang, \\ Indonesia
}

\begin{abstract}
Info Artikel ABSTRAK
Sejarah Artikel:

Diterima:

3 Agustus 2020

Disetujui:

23 Desember 2020

Dipublikasikan:

28 Desember 2020

Penggunaan radiografi konvensional sudah mulai ditinggalkan dan bergeser pada sistem digital yaitu Digital Radiography (DR). Tingginya hasil kualitas citra radiografi bermanfaat dalam penentuan diagnose dan optimasi dosis. Tujuan penelitian ini adalah untuk mengetahui pengaruh faktor eksposi terhadap nilai kontras DR pada citra phantom objek kontras tinggi dan rendah. Metode yang digunakan terdiri dari pembuatan phantom, eksposi phantom dan analisis citra hasil eksposi. Penelitian ini dilakukan dengan menggunakan phantom sebagai objek citra. Phantom dibuat dengan spesifikasi berbagai objek yang mewakili kontras tinggi dan rendah. Phantom dieksposikan dengan variasi arus waktu dan tegangan. Eksposi phantom dilakukan

Keywords: Digital Radiography, Phantom, image dengan memvariasikan tegangan tabung sinar-X yaitu $50 \mathrm{kV}, 60 \mathrm{kV}, 70 \mathrm{kV}$ dan $81 \mathrm{kV}$ serta variasi nilai arus-waktu yaitu 1,6 mAs; 2 mAs; 4 mAs; 8 mAs; 16 mAs dan 31,5 mAs. Eksposi phantom pada sistem DR dilakukan dengan jarak Focus to Film Distance (FFD) $100 \mathrm{~cm}$. Hasil analisis didapatkan bahwa pada variasi arus waktu, semakin besarnya nilai kontras pada citra maka akan semakin besar pula nilai arus waktunya. Pada variasi tegangan menunjukkan bahwa semakin besar tegangan yang digunakan maka akan semakin kecil nilai kontras yang dihasilkan.
\end{abstract}

\begin{abstract}
The use of conventional radiography has replaced to a digital system, namely Digital Radiography (DR). The high result of radiography image quality is useful in determining the diagnosis and optimize dosage. The aim of this study was to determine the effect of the exposure factor on the contrast value of DR on the phantom image of high and low contrast objects. The method that used consists of fabricating phantoms, exposing the phantoms and analyzing the exposed images. This research was conducted using phantom as an image object. Phantom is made with various object specifications that represent high and low contrast. Phantom is exposed to variations in the current, time and voltage. The exposed of phantom using variations in the value of $X$-ray tube voltage whose values were $50 \mathrm{kV}, 60 \mathrm{kV}, 70 \mathrm{kV}$ and $81 \mathrm{kV}$ then using variations in the value of currenttime were $1.6 \mathrm{mAs} ; 2 \mathrm{mAs} ; 4 \mathrm{mAs} ; 8 \mathrm{mAs} ; 16 \mathrm{mAs}$ and $31.5 \mathrm{mAs}$. Phantom exposure in the DR system was carried out with a Focus to Film Distance (FFD) distance of $100 \mathrm{~cm}$. The result is found that from the time flow variation, the greater the contrast value in the image, the greater the time flow value. From the voltage variation shows that the greater the voltage used, the smaller the resulting contrast value.
\end{abstract}

(C) 2020 Universitas Negeri Semarang

$\begin{array}{lr}\text { Alamat korespondensi: } & \text { p-ISSN 2088-1509 } \\ \text { Program Studi Pendidikan Kedokteran, Fakultas Kedokteran, UNISSULA } & \text { e-ISSN 2684-978X } \\ \text { E-mail: andhika.d.anggara@gmail.com } & \end{array}$




\section{PENDAHULUAN}

Penggunaan film konvensional dalam radiografi sudah mulai ditinggalkan dan bergeser pada sistem digital (Busch dkk., 2006). Pencitraan digital sudah menjadi andalan di bidang medis karena keakuratan dan ketepatannya (Brough dkk., 2013). Radiografi dengan sistem digital lebih dipilih karena mempunyai banyak keuntungan antara lain yaitu besarnya efisiensi deteksi, dynamic range yang tinggi, bisa dilakukan perbaikan kontras dan dapat diolah lebih lanjut. Salah satu bentuk pengolahannya adalah dengan computer-aided diagnosis (CAD) (Suryanarayanan dkk., 2002; Aghmasheh dkk., 2012).

Radiografi sangat berkaitan erat dengan kualitas citra. Dalam dunia kedokteran, kualitas citra yang dihasilkan oleh suatu modalitas radiografi merupakan hal yang sangat penting karena berkaitan dengan penentuan diagnosa penyakit pada pasien (Gharehaghaji, 2019). Kualitas citra yang baik adalah yang memiliki resolusi spasial yang tinggi, nilai kontras yang tinggi dan noise yang rendah. Nilai kontras tersebut berhubungan dengan tingkat keabuan suatu citra. Nilai keabuan berkaitan erat dengan kemampuan organ dalam tububh manusia dalam menyerap sinar-X. Kemampuan organorgan manusia (pasien) dalam menyerap sinar-X yang dihasilkan oleh suatu modalitas berbeda-beda sehingga nilai keabuan yang dihasilkan pada citra beragam. Hal ini sangat penting diperhatikan untuk meminimalisir kesalahan diagnosa.

Kualitas citra yang dihasilkan oleh modalitas radiografi juga bergantung pada sistem radiografi yang digunakan (Sheridan, 2016). Kualitas citra yang dihasilkan dalam sistem digital radiografi berpengaruh pada optimasi paparan dosis terhadap pasien sehingga pemilihan modalitas radiografi juga harus diperhatikan (Willis, 2009). Dalam sistem radiografi digital, kualitas citra dipengaruhi oleh tiga faktor penting, yaitu (1) tegangan tabung, merepresentasikan daya tembus energi foton dalam tabung sinar-X, (2) arus tabung, berhubungan dengan kuantitas foton yang dihasilkan, (3) waktu eksposi, merepresentasikan lamanya pemaparan (Andria dkk., 2016). Ketiga faktor tersebut kemudian dikenal dengan nama faktor eksposi. Pengaturan faktor eksposi yang tepat dapat mengasilkan kontras radiografi yang optimal (Dhahryan dkk., 2012). Muttaqin dan Susilo (2017) menemukan bahwa diperlukan adanya optimasi faktor eksposi dalam pengambilan citra untuk menghasilkan kualitas citra yang baik. Dalam penelitian tersebut juga mengungkapkan bahwa semakin tinggi tegangan yang digunakan maka nilai kontras yang dihasilkan semakin rendah. Hal ini dikuatkan oleh Sparzinanda (2017) yang menyatakan bahwa perubahan tegangan tabung sinar-X berpengaruh terhadap tingkat keabuan citra yang dihasilkan.

Hasil citra radiografi digital memiliki keuntungan dalam pengaturan kecerahan dan kontras. Namun pengaturan tersebut justru meningkatkan noise pada citra. Pengurangan noise pada radiografi digital dapat dilakukan dengan pengaturan image filter. Namun berakibat detail citra akan menghilang (Yoon dkk., 2018). Detail citra digital radiografi sangat penting untuk mendeteksi objek di dalam tubuh. Densitas organ dalam tubuh manusia mempunyai nilai yang berbeda-beda. Kemajemukan nilai densitas organ tubuh manusia menuntut suatu citra radiografi harus mempunyai tingkat keterbacaan yang tinggi terutama dalam pembedaan objek organ. Perbedaan keberadaan organ ditunjukkan oleh nilai skala keabuan yang berbeda. Tujuan penelitian ini adalah untuk mengetahui pengaruh faktor eksposi terhadap nilai kontras radiografi digital pada citra phantom objek kontras tinggi dan rendah.

\section{METODE}

Penelitian ini menggunakan Digital Radiography (DR) yang dimiliki oleh Rumah Sakit Nasional Diponegoro (RSND) Universitas Diponegoro Semarang. Sebelum pemaparan dengan DR dilakukan, modalitas penunjang seperti phantom yang akan dijadikan objek citra dipersiapkan. Phantom yang digunakan terbuat dari akrilik yang di dalamnya diberi berbagai bahan kontras tinggi dan rendah sebagai bahan yang merepresentasikan organ atau jaringan-jaringan dalam tubuh manusia. Bahan-bahan inilah yang dianalisis nilai kontrasnya setelah terbentuknya citra. Bahan utama phantom merupakan akrilik yang dipilih karena mempunyai densitas yang mendekati nilai densitas air (Sofyan dkk., 2017). Densitas air menjadi acuan karena sebgian besar tubuh manusia tersusun atas air. Bahan kontras tinggi yang dipilih merupakan bahan yang mempunyai selisih densitas cukup besar terhadap 
densitas air, sedangkan bahan kontras rendah mempunyai selisih densitas cukup kecil terhadap densitas air. Dimensi phantom adalah $15 \times 10 \times 2 \mathrm{~cm}^{3}$.

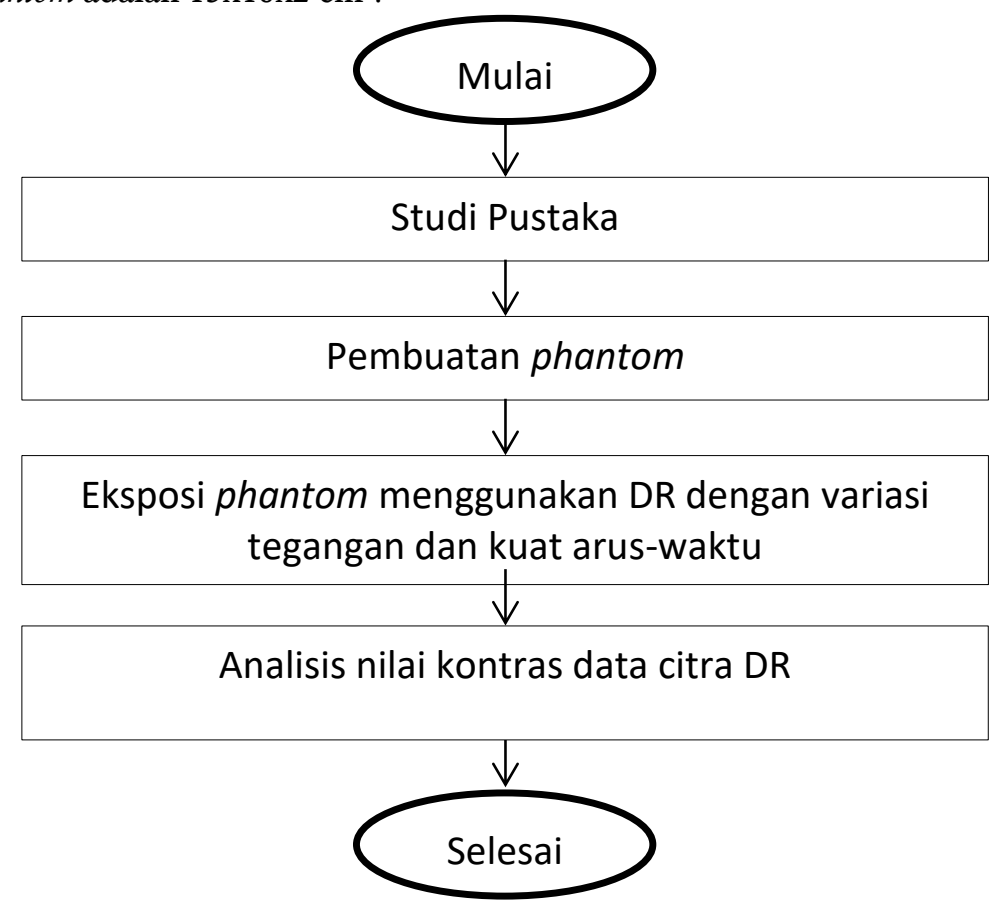

Gambar 1. Diagram alir penelitian

Phantom yang sudah dipersiapkan dieksposi dengan variasi nilai arus-waktu dan tegangan tabung sinar-X. Dengan variasi tegangan tabung sinar-X secara berturut-turut adalah $50 \mathrm{kV}, 60 \mathrm{kV}$, $70 \mathrm{kV}$ dan $81 \mathrm{kV}$. Dari tiap-tiap variasi tegangan tersebut dilakukan variasi arus tabung sinar-X sebanyak enam kali, yaitu 1,6 mAs; 2 mAs; 4 mAs; 8 mAs; 16 mAs dan 31,5 mAs. Eksposi phantom pada sistem DR dilakukan dengan jarak Focus to Film Distance (FFD) $100 \mathrm{~cm}$.

Data yang dihasilkan dari eksposi phantom selanjutnya diolah dan dianalisis dengan bantuan perangkat lunak Matlab. Perangkat lunak Matlab digunakan untuk mendapatkan nilai greylevel dari citra. Dari nilai greylevel tersebut akan digunakan untuk menghitung nilai.

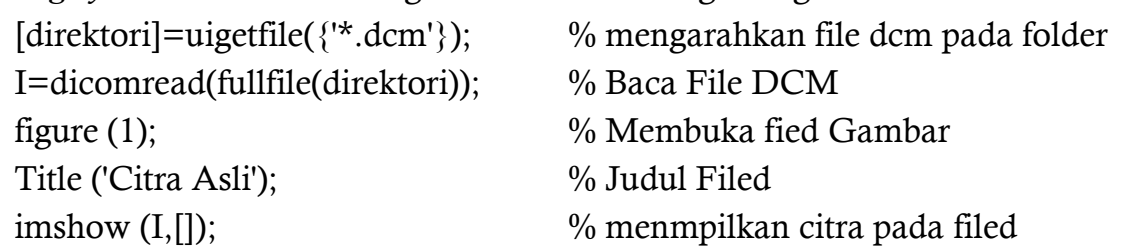

Citra yang dimunculkan melalui perangkat lunak Matlab memiliki data nilai resolusi serta nilai greylevel dari masing-masing pixel citra. Nilai greylevel yang didapatkan tersebut selanjutnya diolah dengan peranti lunak Microsoft Excel. Data yang didapatkan dalam citra akan menunjukkan pengaruh variasi arus-waktu dan tegangan tabung sinar-X terhadap nilai kontras pada citra. 

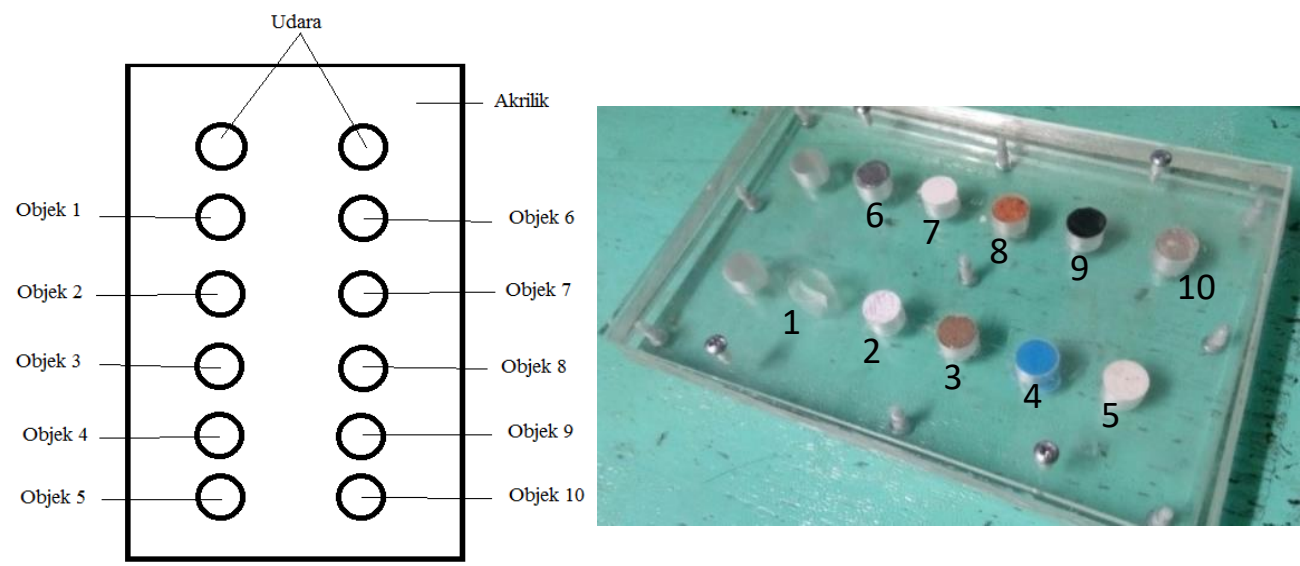

Gambar 2. Phantom akrilik dengan penomoran objek

Tabel 1. Bahan dan densitas objek di phantom

\begin{tabular}{clcc}
\hline Objek & Bahan & Densitas $\left(\mathrm{g} / \mathrm{cm}^{3}\right)$ & $\begin{array}{c}\text { Objek } \\
\text { Kontras }\end{array}$ \\
\hline 1 & Resin / Polyester & 1,20 & Rendah \\
\hline 2 & Kertas & 1,21 & Rendah \\
\hline 3 & Polyethilane & 0,96 & Rendah \\
\hline 4 & Lilin & 0,93 & Rendah \\
\hline 5 & Polypropilane & 0,90 & Rendah \\
\hline 6 & Aluminium & 2,64 & Tinggi \\
\hline 7 & Batu Bata Merah & 1,92 & Tinggi \\
\hline 8 & Gypsum & 2,32 & Tinggi \\
\hline 9 & Karet & 1,52 & Tinggi \\
\hline 10 & Semen & 2,16 & Tinggi
\end{tabular}

\section{HASIL DAN PEMBAHASAN}

Eksposi menggunakan DR didapatkan citra phantom dengan variasi nilai tegangan dan arus waktu. Variasi tersebut mempengaruhi nilai kontras pada citra yang dihasilkan. Setiap satu nilai variasi menghasilkan nilai kontras yang berbeda terhadap nilai variasi yang lainnya, dari variasi terkecil yaitu $50 \mathrm{kV}-1,6 \mathrm{mAs}$ hingga variasi terbesar $81 \mathrm{kV}-31,5 \mathrm{mAs}$. Variasi nilai tersebut menunjukkan hasil nilai kontras yang berbeda-beda pada objek kontras rendah maupun objek kontras tinggi.

Distribusi nilai kontras untuk objek kontras rendah dengan penggunaan tegangan $50 \mathrm{kV}, 60$ $\mathrm{kV}, 70 \mathrm{kV}$, dan $81 \mathrm{kV}$ ditunjukkan pada Gambar 3. Pada objek kontras rendah penggunaan aruswaktu yang diperbesar diikuti dengan kenaikan nilai kontras, kecuali pada nilai arus waktu tertentu pada tiap tegangan. Walaupun kenaikan kontras berpengaruh pada berkurangnya noise pada citra (Riyanto dkk., 2019) ternyata pada nilai tertentu arus-waktu yang tinggi pada penggunaan nilai tegangan yang cukup besar dapat mengakibatkan akumulasi energi eksposi yang besar. Hal ini berdampak besarnya daya penetrasi sinar X yang relatif jauh lebih besar daripada yang diserap oleh objek. Semakin besar arus yang digunakan maka semakin banyak berkas sinar-X yang dilepaskan oleh tabung sinar-X sehingga berkas sinar-X yang diterima phantom pun semakin banyak. Semakin besar 
intensitas yang ditembakkan berdampak berkas yang diserap oleh phantom semakin banyak namun berkas yang diteruskan pun juga semakin banyak. Besarnya berkas yang diteruskan maupun yang diserap inilah yang berpengaruh pada besarnya nilai kontras yang dihasilkan. Naiknya nilai tegangan juga berpengaruh pada besarnya energi berkas sinar-X yang ditembakkan. Semakin besar tegangan maka semakin besar pula energi sinar-X yang ditembakkan.

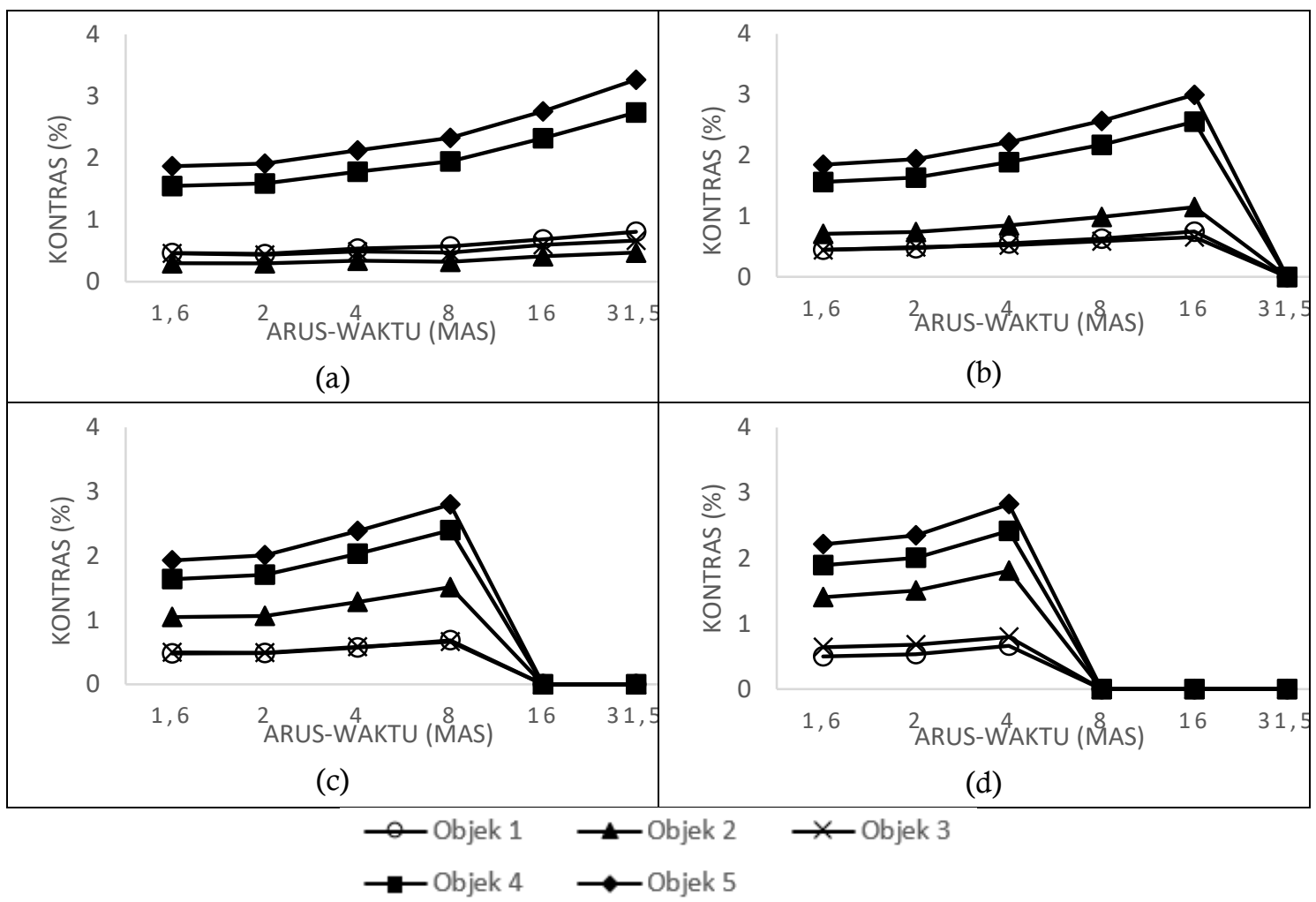

Gambar 3. Nilai kontras untuk objek kontras rendah dengan penggunaan tegangan: (a) $50 \mathrm{kV}$, (b) $60 \mathrm{kV}$, (c) $70 \mathrm{kV}$, dan (d) $81 \mathrm{kV}$

Perubahan signifikansi nilai kontras antar objek seiring bertambahnya tegangan seperti ditunjukkan pada Gambar 3. Nilai resolusi kontrasnya didapatkan bahwa semakin besarnya tegangan dapat menghasilkan perbedaan nilai kontras pada objek yang mempunyai densitas yang mirip. Perbedaan tersebut dapat dilihat pada objek 1 dan objek 2 yang semakin tampak perbedaan nilai kontrasnya ketika adanya kenaikan tegangan.

Distribusi nilai kontras untuk objek kontras tinggi dengan penggunaan tegangan $50 \mathrm{kV}, 60 \mathrm{kV}$, $70 \mathrm{kV}$, dan $81 \mathrm{kV}$ ditunjukkan pada Gambar 4. Gambar 4 menunjukkan bahwa pada objek kontras tinggi mempunyai distribusi nilai kontras yang relative mirip dengan objek kontras rendah. Hanya saja kenaikan nilai kontras pada objek kontras tinggi cenderung lebih tinggi dari pada objek kontras rendah pada tiap kenaikan arus-waktunya. Akan tetapi pada keduanya sama-sama mengalami penurunan nilai kontras pada nilai arus-waktu yang sama dan pada tegangan yang sama.

Pada objek kontras rendah maupun kontras tinggi dapat dilihat bahwa nilai kontras semakin naik namun hanya pada tegangan $50 \mathrm{kV}$ saja yang konstan naik pada variasi arus-waktu. Pada tegangan $60 \mathrm{kV}$ hingga $81 \mathrm{kV}$ terjadi penurunan kontras pada saat arus waktu yang relative besar. Pada tegangan $60 \mathrm{kV}$ nilai kontras turun secara tajam pada arus $31,5 \mathrm{mAs}$. Bahkan pada arus 31,5 mAs objek kontras rendah ada yang tak tampak terbedakan atau nilai kontrasnya nol. Hal ini menunjukkan pada penelitian ini saat tegangan $60 \mathrm{kV}$ DR hanya mampu menghasilkan citra dari phantom yang digunakan dengan objek yang terbedakan hingga pada saat nilai arus tertinggi $16 \mathrm{mAs}$. 
Begitu pula pada tegangan $70 \mathrm{kV}$ dan $81 \mathrm{kV}$ yang mulai mengalami penurunan nilai kontras pada masing-masing di atas $8 \mathrm{mAs}$ dan $4 \mathrm{mAs}$. Semakin besar energi sinar-X maka semakin besar pula daya tembusnya terhadap suatu benda. Oleh karena itu apabila tegangan dinaikkan maka semakin besar daya tembus sinar-X yang dihasilkan. Hal ini berdampak citra yang dihasilkan menjadi semakin menuju ke warna yang lebih gelap. Oleh karena itu tegangan $70 \mathrm{kV}$ dan $81 \mathrm{kV}$ menghasilkan citra yang lebih gelap daripada tegangan $60 \mathrm{kV}$.

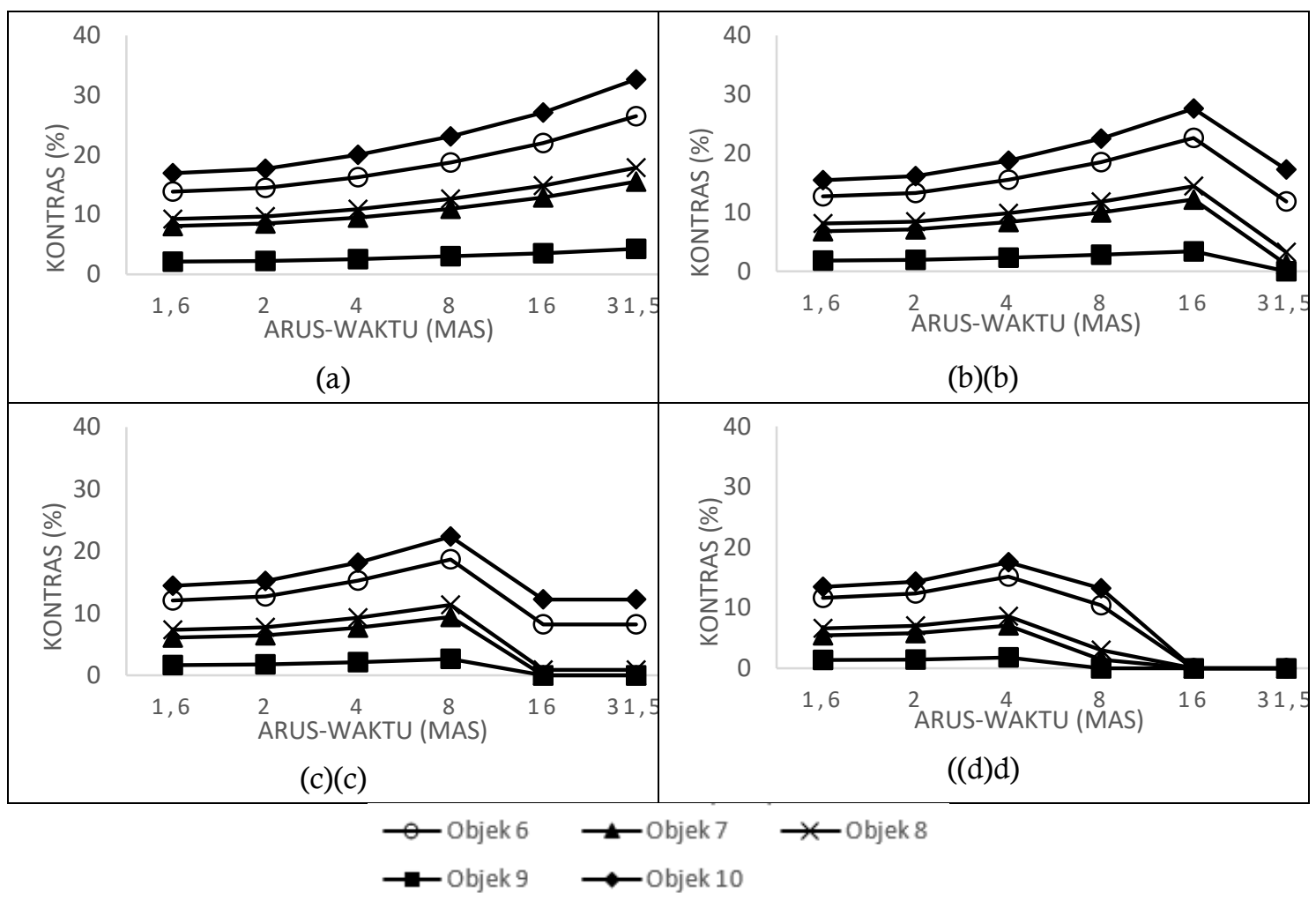

Gambar 4. Nilai kontras untuk objek kontras tinggi dengan penggunaan tegangan: (a) 50 $\mathrm{kV}$, (b) $60 \mathrm{kV}$, (c) $70 \mathrm{kV}$, dan (d) $81 \mathrm{kV}$

Pada DR yang telah digunakan didapatkan bahwa kenaikan nilai kontras hanya terjadi sampai nilai arus tertentu saja dan terjadi pada semua objek baik objek kontras rendah maupun kontras tinggi. Dari variasi tegangan maupun arus waktu menunjukkan bahwa DR mempunyai kemampuan yang baik dalam menghasilkan citra dengan kontras yang rendah maupun tinggi namun dengan Batasan nilai variasi tertentu. Hal ini dapat dilihat nilai kontras yang didapatkan serta terbedakannya bahan dengan densitas yang hampir sama. Baiknya nilai kontras tidak lepas dari nilai besarnya Detective Quantum Eficiency (DQE) yaitu nilai efisiensi detektor dalam meneruskan berkas yang melewati objek. Dengan sistem deteksi yang berbeda maka pastinya akan menghasilkan kualitas citra yang berbeda, karena citra yang dihasilkan dalam radiografi bergantung dari efisiensi detektor (Buzug, 2008). DR mempunyai nilai DQE sebesar 66\%, dan ini dua kali lipat nilainya dari alat radiografi CR (Granfors, 1999). DQE yang kecil berdampak pada banyaknya noise yang muncul pada citra (McEntee dkk., 2007). Semakin besar noise maka semakin berkurangnya nilai kontras dan berdampak pada penurunan kualitas citra.

Semakin besar tegangan yang digunakan maka semakin besar daya tembus dari berkas radiasi. Oleh karena itu semakin besar tegangan yang digunakan maka semakin kecil nilai kontras yang dihasilkan karena berkas yang terserap objek sangat sedikit yang menyebabkan berkas yang diteruskan objek tidak terlihat berbeda dengan berkas yang tidak mengenai objek. Sedangkan semakin besar arus 
waktu yang digunakan justru semakin manikkan nilai kontras. Hal ini disebabkan semakin besar arus waktu yang digunakan maka semakin banyak pula berkas foton sinar-X yang ditembakkan dan akan berdampak banyak pula jumlah berkas foton yang tertangkap oleh detektor. Semakin banyak foton yang tertangkap oleh detektor akan menghasilkan citra yang semakin detail.

Besarnya nilai tegangan dan arus waktu berpengaruh pada dosis yang akan diterima oleh pasien. Salah satu hal yang sangat penting dalam sistem diagnostik adalah manajemen dosis pada pasien, tanpa mengesampingkan kualitas citra yang dihasilkan (Seeram dkk., 2013). Optimasi dosis sangatlah penting untuk pasien terutama anak-anak. Anak-anak mempunyai ukuran tubuh lebih kecil dan lebih radiosensitif sehingga pemilihan alat diagnostik dengan akurasi yang tinggi sangatlah penting agar citra yang dihasilkan tepat merepresentasikan objek dan tidak perlu pengambilan ulang citra. Oleh karena itu dengan penelitian ini diharapkan bisa menjadi pandangan dalam pemilihan dosis secara optimal.

\section{SIMPULAN}

Dari hasil penelitian yang didapatkan menunjukkan bahwa semakin besar nilai tegangan yang digunakan berdampak semakin kecil nilai kontras yang dihasilkan, sedangkan semakin besar nilai arus waktu yang digunakan maka semakin besar pula nilai kontras yang dihasilkan pada citra. Hali ini berlaku pada objek kontras tinggi maupun rendah. Besarnya tegangan yang digunakan bedampak lebih gelapnya citra phantom yang dihasilkan. Penggunaan optimal pada tegangan $50 \mathrm{kV}$ berlaku untuk semua variasi nilai arus waktu yang dipakai, $60 \mathrm{kV}$ hanya sampai pada arus waktu $16 \mathrm{mAs}, 70$ $\mathrm{kV}$ pada $8 \mathrm{mAs}$ dan $81 \mathrm{kV}$ pada $4 \mathrm{mAs}$.

\section{REFERENSI}

Aghmasheh, F., Bardal, R., Reihani, Z., Moghaddam, M.A., Taban, S.R., Fallahzadeh, F., dan Ahmad, A., 2012, Comparative Study of The Effect of Direct and Indirect Digital Radiography on The Assessment of Proximal Caries, Indian Journal of Dentistry, Vol. 4(2), Hal. 83-87.

Andria, G., Attivissimo, F., Guglielmi, G., Lanzolla, A.M.L., Maiorana, A., dan Mangiantini, M., 2016, Towards Patient Dose Optimization In Digital Radiography, Measurement, Vol. 79, Hal. 331-338.

Andria, G., Attivissimo, F., Nisio, A., Lanzolla, A.M.L., Guglielmi, G., Terlizzi, R., 2014, Dose Optimization In Chest Radiography: System And Model Characterization Via Experimental Investigation. IEEE Trans Instrum Meas, Vol. 63(5), Hal.1163-1170.

Brough, A.L., Bennett, J., Morgan, B., Black, S., dan Rutty, G.N., 2013, Anthropological Measurement of The Juvenile Clavicle Using Multi-detector Computed Tomography Affirming Reliability, Journal Forensic Science, Vol. 58(4), Hal. 946-951.

Busch, H.P., dan Faulkner, K., 2005, Image Quality and Dose Management in Digital Radiography: A New Paradigm for Optimisation, Radiation Protection Dosimetry, Vol. 117, Hal. 143-147.

Buzug, T.M., 2008, Computed Tomography - From Photon Statistics to Modern Cone-Beam CT, Springer, Lubeck.

Dhahryan, D., Azam, M., 2012, Pengaruh Teknik Tegangan Tinggi Terhadap Entrasce Skin Exposure( ESE ) dan Laju Paparan Radiasi Hambur Pada Pemeriksaan Abdomen, Berkala Fisika, Vol 12 (1), Hal. 21-26.

Gharehaghaji, N., Khezerloo, D., Abbasiazar, T., 2019, Image quality assessment of the digital radiography units in Tabriz, Iran: A phantom study, Journal of Medical Signals \& Sensors, Vol. $9(2)$

Granfors, P., 1999, Performance characteristics of an amorphous silicon flat panel X-ray imaging detector. Proceedings of SPIE, Vol. 3659, Hal. 480-490 
McEntee, M., Frawley, H., dan Brennan, P.C., 2007, A Comparison of Low Contrast Performance For Amorphous Silicon/Caesium Iodida Direct Radiography With a Computed Radiography: A Contrast Detail Phantom Study, Radiography, Vol. 13, Hal. 89-94.

Muttaqin, R., Susilo, S., 2017, Uji banding kualitas citra radiograf sistem radiografi digital modifikasi terhadap computed radiography system dengan metode Contrass to Noise Ratio, Physics Communication, Vol. 1(1).

Riyanto, S., Budi, W. S., Anam, C., 2019, Pengaruh Arus Tabung Terhadap Noise dan Kontras Citra Pad Pesawat CT Scan, Berkala Fisika, Vol. 22(3), Hal. 105-109

Seeram, E., Davidson, R., Bushong, S., dan Swan, H., 2013, Radiation Dose Optimization Research: Exposure Technique Approaches in CR Imaging - A Literature Review, Radiography, Vol. 19, Hal. 331-338.

Sheridan, N., dan McNulty, J.P., 2016, Computed Radiography Versus Indirect Digital Radiography For The Detection of Glass Soft-Tissue Foreign Bodies, Radiography, Vol. 22, Hal. 223-227.

Sofyan, M., Hidayati, A. O., Mayani, A. N., 2017, Pembuatan Phantom Dari Gips Sebagai Pengganti Tulang Manusia dan Bahan Akrilik Sebagai Pengganti Soft Tissue, Journal of Health, Vol. 4(2), Hal. 107-113.

Sparzinanda, E., Nehru, N., Nurhidayah, N., 2017, Pengaruh Faktor Eksposi Terhadap Kualitas Citra Radiografi, Journal Online of Physics, Vol. 3 (1)

Suryanarayanan, S., Karrellas, A., Vedantham, S., Ved, H., Baker, S.P., dan D’Orsi, C.J., 2002, FlatPanel Digital Mammography System: Contrast-Detail Comparison Between Screen-Film Radiographs and Hard-Copy Images, Radiology, Vol. 225(3), Hal. 801-807.

Willis, C.E., 2009, Optimizing Digital Radiography of Children, European Journal of Radiology, Vol. 72, Hal. 266-273.

Yoon, D.C., Mol, A., Benn, D.K., dan Benavides, E., 2018, Digital Radiographic Image Processing and Analysis, Dental Clinics of North America, Vol. 62(3), Hal. 341-359. 